\title{
Relationship Between Lignin Metabolism and Lodging Resistance of Culm in Buckwheat
}

\author{
Can Wang ${ }^{1}$, Renwu Ruan ${ }^{1}$, Xiaohui Yuan ${ }^{1}$, Dan $\mathrm{Hu}^{1}$, Hao Yang ${ }^{1}$, Yan $\mathrm{Li}^{1} \&$ Zelin $\mathrm{Yi}^{1}$ \\ ${ }^{1}$ College of Agronomy and Biotechnology, Southwest University, Chongqing, China \\ Correspondence: Zelin Yi, College of Agronomy and Biotechnology, Southwest University, Chongqing 400716, \\ China. E-mail: yzlin1969@126.com
}

Received: June 3, 2014 Accepted: June 23, 2014 Online Published: August 15, 2014

doi:10.5539/jas.v6n9p29 URL: http://dx.doi.org/10.5539/jas.v6n9p29

\begin{abstract}
To disclose the relationship between lignin content and lodging resistance, field experiments were conducted in 2012 and 2013 to investigate the dynamic changes of lignin content, the activities of four enzymes involved in lignin metabolism in culm, as well as the snapping resistance and lodging index of buckwheat. The lignin content and activities of phenylalanine ammonia-lyase (PAL), tyrosine ammonia-lyase (TAL), cinnamyl alcohol dehydrogenase $(\mathrm{CAD})$, and 4-coumarate: $\mathrm{CoA}$ ligase $(4 \mathrm{CL})$ were tested with the $2^{\text {nd }}$ internode of four cultivars with different lodging resistance. The snapping resistance and culm lodging index were determined at anthesis, grain filling, and maturity stages. The lignin content varied significantly among cultivars. The XD cultivar, which showed high resistance to culm snapping and lodging, had higher lignin content and higher activity of PAL, TAL, 4CL, and CAD than other cultivars. The lignin content was significantly negatively correlated with the actual lodging percent $(r=-0.844, P<0.01)$ and the lodging index $(r=-0.832, P<0.05)$, and was significantly positively correlated with the snapping resistance $(r=0.873, P<0.01)$. The activities of PAL, TAL, 4CL, and CAD were positively correlated with lignin content with correlation coefficients of $0.984(P<0.01)$, $0.619(P>0.05), 0.927(P<0.01)$, and $0.862(P<0.01)$, respectively. In conclusion, our results indicate that the activities of PAL and 4CL were the key enzymes that influenced the lignin content, and that the lignin content can be used as main indicators to evaluate the lodging resistance of buckwheat.
\end{abstract}

Keywords: buckwheat, enzyme activity, lignin metabolism, lodging resistance

\section{Introduction}

Buckwheat (Fagopyrum esculentum) is a pseudo-cereal used for human food that belongs to the Polygonaceae family of plants (Lin \& Chai, 2007). Buckwheat grains and other tissues contain a variety of nutrients (Li \& Zhang, 2001) and they are rich in vitamins, especially vitamin B (Kato et al., 2001). Buckwheat grains are an important source of macroelements such as $\mathrm{K}, \mathrm{Ca}, \mathrm{Mg}$, and $\mathrm{Na}$ as well as and microelements such as $\mathrm{Mn}, \mathrm{Zn}, \mathrm{Se}$, and $\mathrm{Cu}$ (Wei et al., 2003). The amino acid composition of buckwheat proteins is well balanced and of a high nutritional value, the significant contents of rutin, catechins and other polyphenols as well as their potential antioxidant activity are also of significance to buckwheat's dietary value (Christa \& Soral-Smietana, 2008). Traditionally, buckwheat is used to treat constipation and bowel upsets and has also been used by diabetics in different parts of Nepal and India (Prakash \& Deshwal, 2013).

Lodging, the permanent displacement of the stem from the vertical, has long been a problem in crop cultivation (Crook \& Ennos, 1994). It can reduce yield, quality of production, and mechanical harvesting efficiency. Shading of leaves and constriction of conducting tissues decreases photosynthesis and lowers yield. Seed set and grain quality are also reduced (Kashiwagi \& Ishimaru, 2004). It was reported that lodging caused a loss of $14.3 \%$ in rice production in coastal regions of Jiangsu China (Zhang et al., 1996) and a loss of as much as $8.3 \%$ of average grain yield in spring wheat (Tripathi et al., 2004). Lodging is reported to be one of the limiting factors of buckwheat production in Nepal (Baniya, 1990).

Lignin is one of the main components of the cell wall. It fills in the space between cellulose structures to enhance the mechanical strength of plant bodies. Phenylalanine ammonia-lyase (PAL), tyrosine ammonia-lyase (TAL), 4-coumarate: CoA ligase (4CL), and cinnamyl alcohol dehydrogenase (CAD) were found to play an important role in the metabolic pathway of lignin (Boudet et al., 2003). Lignin content was closely related to lodging resistance of culm (Jones et al., 2001). Low lignin content may result in weak mechanical strength of culm and 
the result would be easy to extend to lodging in wheat and oats (Welton, 1928). There are several reports on relationships between morphological characteristics and lodging in buckwheat (Hagiwara et al., 1999; Choi et al., 1995), as well as a method for lodging rate evaluation in buckwheat (Murakami et al., 2012). However, there is no research on lignin metabolism in buckwheat. Therefore, we attempted to find the relationship between lignin metabolism of culm and lodging resistance in buckwheat.

\section{Materials and Methods}

\subsection{Site Description}

The field experiments were conducted in 2012 and 2013 at the Xiema experimental station, Southwest University, in Beibei city, Chongqing municipality, China. The station $\left(19^{\circ} 51^{\prime} \mathrm{N}, 106^{\circ} 37^{\prime} \mathrm{E}\right)$ is located $10 \mathrm{~km}$ south of Southwest University at an elevation of $350 \mathrm{~m}$ above sea level. Annual mean temperature is $18.4^{\circ} \mathrm{C}$. Annual cumulative temperatures above $10{ }^{\circ} \mathrm{C}$ is $5979.5^{\circ} \mathrm{C}$. The frost-free period is $330-350$ days. Annual total solar radiation is $3646 \mathrm{MJ} /\left(\mathrm{m}^{2} \cdot\right.$ year $)$. Annual precipitation is $1203 \mathrm{~mm}$ and annual sunshine duration is $1006.2 \mathrm{~h}$. The area is classified as having a subtropical monsoon climate and the soil at the site is classified as a loamy clay soil, and the $0-100 \mathrm{~mm}$ soil layer contained $12.6 \mathrm{~g} / \mathrm{kg}$ organic matter, $73.2 \mathrm{mg} / \mathrm{kg}$ available $\mathrm{N}, 21.0 \mathrm{mg} / \mathrm{kg}$ available $\mathrm{P}, 106.0 \mathrm{mg} / \mathrm{kg}$ available $\mathrm{K}, 0.84 \mathrm{~g} / \mathrm{kg}$ total $\mathrm{N}, 0.46 \mathrm{~g} / \mathrm{kg}$ total $\mathrm{P}$, and $17.5 \mathrm{~g} / \mathrm{kg}$ total $\mathrm{K}$.

\subsection{Experimental Design and Crop Management}

The experiments had a randomized complete block design with three replicates. The area of the individual plots was $10 \mathrm{~m}^{2}(2 \mathrm{~m} \times 5 \mathrm{~m})$. Four buckwheat cultivars (Table 1) were sown on August 26, 2012 and August 28, 2013. Six rows per cultivar were arranged randomly in each experiment plot and there were 3 guard rows around the area. Plant density for buckwheat was $9 \times 10^{5}$ plants/ha. A compound fertilizer $\left(\mathrm{N}: \mathrm{P}_{2} \mathrm{O}_{5}: \mathrm{K}_{2} \mathrm{O}=15: 15: 15\right)$ was applied at a rate of $300 \mathrm{~kg} / \mathrm{ha}$ when the buckwheat seeds were sown.

Table 1. Characteristics of different buckwheat cultivars

\begin{tabular}{ccccccc}
\hline Cultivar & Origin & $\begin{array}{c}\text { Lodging } \\
\text { resistance }\end{array}$ & $\begin{array}{c}\text { Growth period } \\
(\mathrm{d})\end{array}$ & Plant type & $\begin{array}{c}\text { Plant height } \\
(\mathrm{cm})\end{array}$ & $\begin{array}{c}\text { Yield } \\
(\mathrm{kg} / \mathrm{ha})\end{array}$ \\
\hline XD & China & Strong & 70 & Loose & 109 & 855.82 \\
NQ01 & China & Middle & 63 & Loose & 84 & 686.54 \\
XN01 & China & Middle & 63 & Loose & 79 & 624.51 \\
WK & Ukraine & Weak & 63 & Loose & 68 & 463.24 \\
\hline
\end{tabular}

\subsection{Indicators and Measuring Method}

Lodging stage was recorded from seeding to harvesting. Lodging degree, ranged from 0 to 5 on the basis of the angle between buckwheat culm and ground. The Lodging degree score is 0 when the angle is $76^{\circ}-90^{\circ}, 1$ when it is $61^{\circ}-75^{\circ}, 2$ when it is $46^{\circ}-60^{\circ}, 3$ when it is $31^{\circ}-45^{\circ}$, 4 when it is $16^{\circ}-30^{\circ}$ and 5 when the angle is $0^{\circ}-15^{\circ}$. We investigated lodging plant numbers $\left(\mathrm{N}_{1}\right)$ and total plant numbers $(\mathrm{N})$ of buckwheat in each experiment plot, and then calculated the actual lodging percentage $\left(\mathrm{N}_{1} / \mathrm{N} \times 100 \%\right)$. Lodging degree and actual lodging percentage were recorded in 3 days before all strains had completed seed ripening.

Ten standing plants were selected randomly from one half of each plot, avoiding the outer three rows, to measured the height at center of gravity $(\mathrm{H})$, fresh weight $(\mathrm{M})$ of culm, and snapping resistance of the $2^{\text {nd }}$ internode (S). We then calculated the lodging index $(\mathrm{H} \times \mathrm{M} / \mathrm{S})$ in anthesis, the grain filling stage, and maturity. The methods for these measurements are described by Wei et al. (2008).

The lignin content and activities of PAL, TAL, CAD and 4CL were tested with the $2^{\text {nd }}$ internode at 5, 15, 25, 35, and 45 days after emergence of the $2^{\text {nd }}$ internode according to the method reported by Chen et al. (2011).

\subsection{Statistical Analysis}

There were no significant differences between 2012 and 2013 in snapping resistance of the $2^{\text {nd }}$ internode $(P=$ $0.38)$, lodging index $(P=0.42)$, or lignin content $(P=0.23)$. There were also not significant differences in the activities of PAL $(P=0.19)$, TAL $(P=0.27)$, CAD $(P=0.35)$, and 4CL $(P=0.47)$. Therefore, mean values between 2012 and 2013 were analyzed using SPSS 19. The mean values of three replicates were compared by least significant difference (SSR) at the 5\% level. Microsoft Excel 2003 was used for sorting data and drawing. 


\section{Results}

\subsection{Comparison of Lodging Resistance}

There was no lodging in the XD cultivar, the NQ01 and XN01 cultivars were lodging at maturity, and the WK cultivar was lodging at anthesis (Table 2). The lodging degree and actual lodging percentage of WK were higher than NQ01 and XN01 (Table 2). This indicated that the lodging resistance varied significantly among cultivars and the buckwheat cultivar with earlier lodging time had higher lodging degree and actual lodging percentage than other cultivars.

The snapping resistance of the $2^{\text {nd }}$ internode rose and then fell from anthesis to maturity, and the maximum value appeared in the grain filling stage (Table 3). In the grain filing stage, the snapping resistance of the $2^{\text {nd }}$ internode of XD was significantly higher than NQ01, XN01, and WK (Table 3). The lodging index varied significantly among cultivars, and the lodging index of WK was significantly higher than XD, NQ01, and XN01. WK, also showed low resistance to culm snapping and lodging (Table 3). Thus, buckwheat cultivars were amenable to lodging in the grain filling stage. This may be the result of the rising height at center of gravity.

Table 2. Lodging behavior of different buckwheat cultivars

\begin{tabular}{ccccccc}
\hline \multirow{2}{*}{ Cultivar } & \multicolumn{2}{c}{ Lodging stage } & \multicolumn{2}{c}{ Lodging degree } & \multicolumn{2}{c}{ Actual lodging percentage (\%) } \\
\cline { 2 - 7 } & 2012 & 2013 & 2012 & 2013 & 2012 & 2013 \\
\hline XD & - & - & 0 & 0 & 0 & 0 \\
NQ01 & Maturity & Maturity & 2 & 2 & $44.8 \pm 0.68 \mathrm{~b}$ & $53.35 \pm 0.19 \mathrm{~b}$ \\
XN01 & Maturity & Maturity & 2 & 2 & $45.43 \pm 1.06 \mathrm{~b}$ & $54.00 \pm 0.62 \mathrm{~b}$ \\
WK & Anthesis & Anthesis & 4 & 4 & $79.76 \pm 0.99 \mathrm{a}$ & $88.67 \pm 1.01 \mathrm{a}$
\end{tabular}

Note. The data are expressed as the average \pm SD of three replications $(\mathrm{n}=3)$. Different letters indicate significant differences $(P<0.05)$.

Table 3. Changes of snapping resistance and lodging index in different buckwheat cultivars

\begin{tabular}{ccccccc}
\hline \multirow{2}{*}{ Cultivar } & \multicolumn{3}{c}{ Snapping resistance $(\mathrm{g})$} & \multicolumn{2}{c}{ Lodging index $(\mathrm{cm} \cdot \mathrm{g} / \mathrm{g})$} \\
\cline { 2 - 7 } & Anthesis & $\begin{array}{c}\text { Grain filling } \\
\text { stage }\end{array}$ & Maturity & Anthesis & $\begin{array}{c}\text { Grain filling } \\
\text { stage }\end{array}$ & Maturity \\
\hline XD & $438.17 \pm 6.01 \mathrm{a}$ & $817.60 \pm 2.27 \mathrm{a}$ & $756.49 \pm 1.30 \mathrm{a}$ & $0.26 \pm 0.28 \mathrm{c}$ & $0.56 \pm 0.01 \mathrm{c}$ & $0.49 \pm 0.02 \mathrm{c}$ \\
NQ01 & $307.80 \pm 1.88 \mathrm{~b}$ & $560.55 \pm 1.59 \mathrm{~b}$ & $423.82 \pm 9.90 \mathrm{~b}$ & $0.64 \pm 0.05 \mathrm{~b}$ & $0.92 \pm 0.03 \mathrm{~b}$ & $0.82 \pm 0.06 \mathrm{~b}$ \\
XN01 & $303.28 \pm 0.95 \mathrm{~b}$ & $554.76 \pm 0.70 \mathrm{~b}$ & $413.23 \pm 9.51 \mathrm{~b}$ & $0.70 \pm 0.04 \mathrm{~b}$ & $1.04 \pm 0.03 \mathrm{~b}$ & $0.91 \pm 0.11 \mathrm{~b}$ \\
WK & $183.62 \pm 1.58 \mathrm{c}$ & $356.52 \pm 5.75 \mathrm{c}$ & $296.92 \pm 5.55 \mathrm{c}$ & $2.14 \pm 0.29 \mathrm{a}$ & $3.09 \pm 0.16 \mathrm{a}$ & $2.85 \pm 0.08 \mathrm{a}$
\end{tabular}

Note. The data are expressed as the average $\pm \mathrm{SD}$ of three replications $(\mathrm{n}=3)$. Different letters indicate significantly differences $(P<0.05)$ among cultivars.

\subsection{Change of Lignin Content}

The lignin content varied significantly among cultivars and the lignin contents of all buckwheat cultivars increased rapidly in the culm growth process (Figure 1). In same stage, the lignin content of XD was significantly higher than WK. There were no significant differences between NQ01 and XN01 in any of the stages (Figure 1). This is similar to the variation of snapping resistance of the $2^{\text {nd }}$ internode in each buckwheat cultivar (Table 3). It indicated that buckwheat cultivars with high resistance to culm snapping and lodging had higher lignin content of the $2^{\text {nd }}$ internode.

\subsection{Changes of Activities of PAL, TAL, 4CL and CAD}

All cultivars produced a similar trend in PAL activity of the $2^{\text {nd }}$ internode. It declined in the culm growth process and had not much changed 35 days after emergence of the $2^{\text {nd }}$ internode (Figure $2 \mathrm{~A}$ ). The PAL activity of the $2^{\text {nd }}$ internode in XD was significantly higher than in WK. The biggest difference appeared in the early emergence of the $2^{\text {nd }}$ internode, and the PAL activities of the $2^{\text {nd }}$ internode in NQ01 and XN01 ranged between XD and WK 
(Figure 2A). Thus, buckwheat cultivar with high resistance to lodging had a fast reaction speed in the PAL activity of the $2^{\text {nd }}$ internode, and this provided a guarantee for lignin synthesis.

There was no significant change in TAL activities of the $2^{\text {nd }}$ internode in all buckwheat cultivars before 25 days after emergence of the $2^{\text {nd }}$ internode (anthesis). There was a rising trend that switched to a rapid decline 25 days after emergence of the $2^{\text {nd }}$ internode. The maximum appeared in 35 days after emergence of the $2^{\text {nd }}$ internode (Figure 2B). The performance of TAL activity in the $2^{\text {nd }}$ internode followed the pattern XD $>$ NQ01 $>$ XN01 $>$ WK in the culm growth process (Figure 2B).

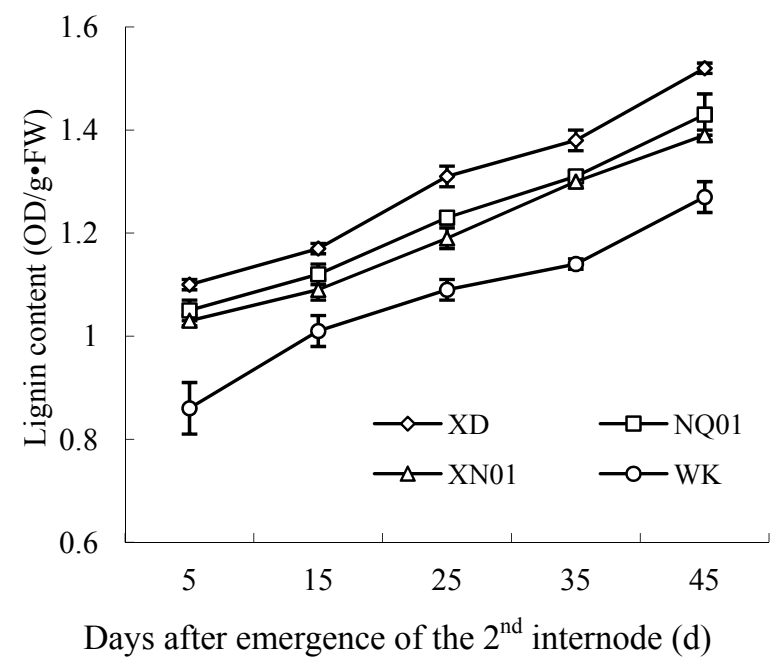

Figure 1. Changes of lignin content in different buckwheat cultivars

Note. Each point represents value in each cultivar per day and is an average \pm SD of three replications $(n=3)$.

The 4CL activities of all buckwheat cultivars increased rapidly at the beginning of the $2^{\text {nd }}$ internode formation, and then decreased rapidly 15 days after emergence of the $2^{\text {nd }}$ internode (Figure $2 \mathrm{C}$ ). There were no significant differences among buckwheat cultivars in 4CL activities of the $2^{\text {nd }}$ internode at 45 days after emergence of the $2^{\text {nd }}$ internode (Figure 2C). The expression of 4CL activities in the $2^{\text {nd }}$ internode followed the trend XD $>$ NQ01 $>$ $\mathrm{XN01}>\mathrm{WK}$ at 5 days, 15 days, 25 days, and 35 days after emergence of $2^{\text {nd }}$ internode (Figure 2C).

There was a bimodal trend changed in CAD activities of all buckwheat cultivars. The first peak appeared at 15 days after emergence of the $2^{\text {nd }}$ internode and the second peak appeared at 35 days after emergence of the $2^{\text {nd }}$ internode (grain filling stage) (Figure 2D). In the grain filling stage, the CAD activity of XD was significantly higher than WK, and there was no significant difference between NQ01 and XN01 (Figure 2D).

3.4 Correlation Analysis Among Lignin Content in Culm, Activities of Lignin Metabolism-related Enzymes, and Lodging Resistance at Grain Filling Stage of Buckwheat

The actual lodging percent was negatively correlated with snapping resistance, lignin content, PAL activity, 4CL activity, and CAD activity with correlation coefficients of $-0.907(P<0.01),-0.844(P<0.01),-0.872(P<0.01)$, $-0.838(P<0.01)$, and $-0.870(P<0.01)$, respectively. The actual lodging percent was significantly positively correlated with lodging index $(r=0.842, P<0.01)$ but not with TAL activity (Table 4$)$. The lodging index was negatively correlated with snapping resistance, lignin content, PAL activity, 4CL activity, and CAD activity with correlation coefficients of $-0.734(P<0.05),-0.832(P<0.05),-0.899(P<0.01),-0.783(P<0.05)$, and -0.787 $(P<0.05)$, respectively, The lodging index was not significantly correlated with TAL activity (Table 4$)$. The snapping resistance was significantly positively correlated with lignin content $(r=0.873, P<0.01)$ but not with PAL activity, TAL activity, 4CL activity, or CAD activity (Table 4). The activities of PAL, TAL, 4CL and CAD were positively correlated with lignin content with correlation coefficients of $0.984(P<0.01), 0.619(P>0.05)$, $0.927(P<0.01)$, and $0.862(P<0.01)$, respectively (Table 4$)$. These results indicated that the lodging resistance was closely related to lignin content and buckwheat which showed high resistance to culm snapping and lodging had higher lignin content. High activities of PAL, 4CL and CAD were the enzymatic basis of increased lignin content. 


\subsection{MLR Analysis Between Lignin Content and Activities of PAL, TAL, 4CL and CAD}

In order to clarify and differentiate the key enzymes that influenced the lignin content of the $2^{\text {nd }}$ internode, a correlation analysis conducted with a single parameter could be insufficient, because several parameters are often interrelated. Therefore, MLR was used to quantify the relationship of lignin content $(y)$ and PAL $\left(x_{1}\right)$, TAL $\left(x_{2}\right), 4 \mathrm{CL}\left(x_{3}\right)$ and CAD $\left(x_{4}\right)$. The MLR equation that optimizes the model for the relationship and the statistics calculated in this analysis excluding not significant items as $y=0.017+0.352 x_{1}+0.090 x_{3}\left(R^{2}=0.961, N=4, F\right.$ $=305.075, P<0.0001)$. The partial regression coefficient of PAL and 4CL were 0.825 and 0.601 , respectively.

Thus, the lignin content was more influenced by activities of PAL and 4CL.
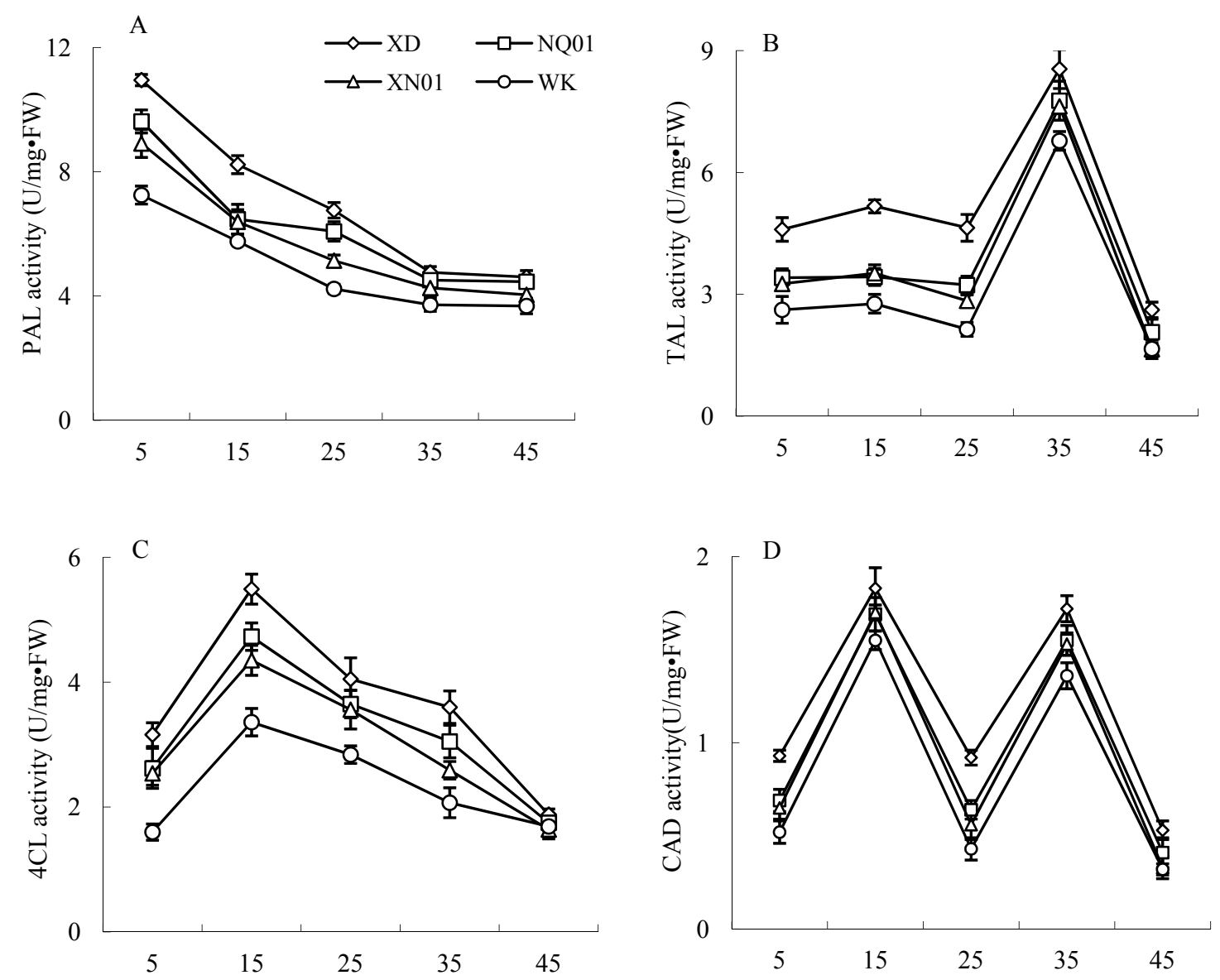

Days after emergence of the $2^{\text {nd }}$ internode (d)

Figure 2. Changes of activities of PAL, TAL, 4CL and CAD in different buckwheat cultivars

Note. Each point represents value in each cultivar per day and is an average $\pm \mathrm{SD}$ of three replications $(\mathrm{n}=3)$.

Table 4. Correlation coefficients among lignin content in culm, activities of lignin metabolism-related enzyme, and lodging resistance at grain filling stage of buckwheat

\begin{tabular}{llllllll}
\hline & $\begin{array}{l}\text { Lodging } \\
\text { index }\end{array}$ & $\begin{array}{l}\text { Snapping } \\
\text { resistance }\end{array}$ & $\begin{array}{l}\text { Lignin } \\
\text { content }\end{array}$ & $\begin{array}{l}\text { PAL } \\
\text { activity }\end{array}$ & $\begin{array}{l}\text { TAL } \\
\text { activity }\end{array}$ & $\begin{array}{l}\text { 4CL } \\
\text { activity }\end{array}$ & $\begin{array}{l}\text { CAD } \\
\text { activity }\end{array}$ \\
\hline Lignin content & & & & $0.984^{* *}$ & 0.619 & $0.927^{* *}$ & $0.862^{* *}$ \\
Snapping resistance & & & $0.873^{* *}$ & 0.587 & 0.061 & 0.553 & 0.598 \\
Lodging index & & $-0.734^{*}$ & $-0.832^{*}$ & $-0.899^{* *}$ & -0.356 & $-0.783^{*}$ & $-0.787^{*}$ \\
Actual lodging percentage & $0.842^{* *}$ & $-0.907^{* *}$ & $-0.844^{* *}$ & $-0.872^{* *}$ & -0.453 & $-0.838^{* *}$ & $-0.870^{* *}$ \\
\hline
\end{tabular}

Note. ${ }^{*}$ and $* *$ are significant at 0.05 and 0.01 probability levels, respectively, ns represent non-significant. 


\section{Discussion}

Lignin plays an important role in improving the strength of plant cell walls and increasing the mechanical intensity of culm, and lignin content has been found to be closely related to the culm rigidity (Lewis \& Yamamoto, 1990; Turner \& Somerville, 1997). For example, the occurrence of lodging was caused by shortage of lignin in culm of wheat (Welton, 1928) and rice (Ookawa \& Ishihara, 1993). In addition, increases in lignin content could significantly improve the mechanical intensity of culm, which further increases the lodging resistance in the culm (Baucher et al., 1998). The present study showed that the lignin contents of all buckwheat cultivars were increased rapidly in the culm growth process (Figure 1) and that the XD cultivar had high resistance to culm snapping and lodging (Table 2 and 3) also had higher lignin content of the $2^{\text {nd }}$ internode (Figure 1) compared with NQ01, XN01, and WK. Furthermore, the lignin content was significantly negatively correlated with actual lodging percent $(r=-0.844, P<0.01)$ and lodging index $(r=-0.832, P<0.05)$, and significantly positively correlated with snapping resistance $(r=0.873, P<0.01)$ (Table 4$)$. In conclusion, our results indicate that the lignin content in culm can be used as an important evaluation index in lodging resistance of culm in buckwheat.

PAL, TAL, 4CL and CAD have been found to be important enzymes in the process of lignin metabolism and play important roles in plant resistance response (Campbell \& Sederoff, 1996). PAL is a rate-limiting enzyme in the shikimic acid pathway. PAL catalyzes the conversion of L-phenylalanine dehydrogenase into trans cinnamic acid. The lignin content in plants was reduced when the PAL activity decreased and the overexpression of PAL activity could significantly increases lignin content (Bate et al., 1994; Osakabe et al., 1995; Sewalt et al., 1997). The present study showed that the PAL activity was significantly positively correlated with lignin content $(r=$ $0.984, P<0.01$ ) (Table 4) and that increases in PAL activity could increases lignin content in the culm of buckwheat. Thus, the PAL activity was closely related to the lodging resistance of culm in buckwheat.

TAL catalyzes the conversion of tyrosine into coumaric acid, which only exists in gramineous plants, and it has been found to play an important role in the metabolic pathway of lignin (Rosler et al., 1997). In the present study, the TAL activity was not significantly positively correlated with lignin content, actual lodging percent, lodging index, or snapping resistance (Table 4). There was no significant change in TAL activities of the $2^{\text {nd }}$ internode in all buckwheat cultivars prior to 25 days after emergence of the $2^{\text {nd }}$ internode (anthesis) (Figure 2B). Therefore, the activity of TAL could not reflected the lodging resistance of culm in buckwheat.

$4 \mathrm{CL}$ is a ligase in lignin metabolism. It catalyzes the conversion of cinnamic acid into the corresponding esters, and the lignin content was significantly decreased in the transgenic plants with inhibition of 4CL (Kajita et al., 1997; Lee et al., 1997). In this study, the 4CL activities of all buckwheat cultivars were increased rapidly at the beginning of the $2^{\text {nd }}$ internode formation. The expression of 4CL activities in the $2^{\text {nd }}$ internode during the culm growth process followed the pattern XD $>$ NQ01 $>$ XN01 $>$ WK (Figure 2C). The activity of 4CL was significantly negatively correlated with actual lodging percent $(r=-0.838, P<0.01)$ and lodging index $(r=$ $-0.783, P<0.05)$ and was significantly positively correlated with lignin content $(r=0.927, P<0.01)$ (Table 4$)$. Thus, the 4CL activity could reflect the lodging resistance of culm in buckwheat.

CAD participates in the last reduction reaction of lignin metabolism (Boudet et al., 2003). In the present study, the CAD activity was significantly negatively correlated with actual lodging percent $(r=-0.870, P<0.01)$ and lodging index $(r=-0.787, P<0.05)$, and CAD activity was significantly positively correlated with lignin content $(r=0.862, P<0.01)$ (Table 4$)$. So the CAD activity could reflect the lodging resistance of culm in buckwheat as well.

The MLR analysis between lignin content and activities of PAL, TAL, 4CL and CAD showed that the activities of PAL and $4 \mathrm{CL}$ were the key enzymes that influenced the lignin content of the $2^{\text {nd }}$ internode.

\section{Conclusion}

XD (a buckwheat cultivar) which showed high resistance to culm snapping and lodging, had higher lignin content and higher activities of PAL, TAL, 4CL and CAD than other buckwheat cultivars. The lignin content could be used as an important indicator to evaluate lodging resistance of buckwheat and the activities of PAL and $4 \mathrm{CL}$ were the key enzymes that influenced the lignin content.

\section{Acknowledgements}

This study was supported by "Fundamental Research Funds for the Central Universities" (XDJK2014D012 and 2362014XK09) and "Chongqing Buckwheat Industry System Innovation Team" (CQCYT2011001). 


\section{References}

Baniya, B. K. (1990). Buckwheat in Nepal. Fagopyrum, 10, 86-94.

Bate, N. J., Orr, J., Ni, W., Meromi, A., Nadler-Hassar, T., Doemer, P. W., ... Elkind, Y. (1994). Quantitative relationship between phenylalanine ammonia-lyase levels and phenylpropanoid accumulation in transgenic tobacco identifies a rate-determining step in natural product synthesis. Proceedings of the National Academy Sciences, 91, 7608-7612. http://dx.doi.org/10.1073/pnas.91.16.7608

Baucher, M., Monties, B., Montagu, M. V., \& Boerjan, W. (1998). Biosynthesis and genetic engineering of lignin. Critical Reviews in Plant Sciences, 17, 125-197. http://dx.doi.org/10.1080/07352689891304203

Boudet, A.M., Kajita, S., Grima-Pettenati, J., \& Goffner, D. (2003). Lignins and lignocellulosics: a better control of synthesis for new and improved uses. Trends in Plant Scicece, 8, 576-581. http://dx.doi.org/10.1016/j.tplants.2003.10.001

Campbell, M. M., \& Sederoff, R. R. (1996). Variation in lignin content and composition (Mechanisms of control and implications for the genetic improvement of plants). Plant Physiology, 110, 3-13. http://dx.doi.org/10.1104/pp.110.1.3

Chen, X. G., Shi, C. Y., Yin, Y. P., Wang, Z. L., Shi, Y. H., Peng, D. L., ... Cai, T. (2011). Relationship between lignin metabolism and lodging resistance in wheat. Acta Agronomica Sinica, 37, 1616-1622. http://dx.doi.org/10.3724/SP.J.1006.2011.01616

Choi, B. H., Cho, S. H., Kim, S. K., Song, D. Y., Park, K. Y., \& Park, R. K. (1995). Agronomic characteristics and productivity of genetic resources of buckwheat (Fagopyrum esculentum Moench.) and their breeding technology. Current Advances in Buckwheat Research (pp. 97-107). Japan: Shishu University Press.

Christa, K., \& Soral-Śmietana, M. (2008). Buckwheat grains and buckwheat products-nutritional and prophylactic value of their components - A review. Czech Journal of Food Science, 26, 153-162.

Crook, M. J., \& Ennos, A. R. (1994). Stem and root characteristics associated with lodging resistance in four winter wheat cultivars. The Journal of Agriculural Science, 123, 167-174. http://dx.doi.org/10.1017/S0021859600068428

Hagiwara, M., Izusawa, H., Inoue, N., \& Matano, T. (1999). Varietal differences of shoot growth characters related to lodging in Tartary buckwheat. Fagopyrum, 16, 67-72.

Jones, L., Ennos, A. R., \& Turner, S. R. (2001). Cloning and characterization of irregular xylem4 (irx4): a severely lignin-deficient mutant of Arabidopsis. The Plant Journal, 26, 205-216. http://dx.doi.org/10.1046/j.1365-313x.2001.01021.x

Kajita, S., Hishiyama, S., Tomimura, Y., Katayama, Y., \& Omori, S. (1997). Structural characterization of modified lignin in transgenic tobacco plants in which the activity of 4-coumarate: Coenzyme A ligase is depressed. Plant physiology, 114, 871-879. http://dx.doi.org/10.1104/pp.114.3.871

Kashiwagi, T., \& Ishimaru, K. (2004). Identification and functional analysis of a locus for improvement of lodging resistance in rice. Plant physiology, 134, 676-683. http://dx.doi.org/10.1104/pp.103.029355

Kato, N., Kayashita, J., \& Tomotake, H. (2001). Nutritional and physiological functions of buckwheat protein. Recent Research Developments in Nutrition, 4, 113-119.

Lee, D., Meyer, K., Chapple, C., \& Douglas, C. J. (1997). Antisense suppression of 4-coumarate: Coenzyme A ligase activity in Arabidopsis leads to altered lignin subunit composition. Plant Cell, 9, 1985-1998. http://dx.doi.org/10.1105/tpc.9.11.1985

Lewis, N. G., \& Yamamoto, E. (1990). Lignin: occurrence, biogenesis and biodegradation. Annual Review of Plant Biology, 41, 455-496. http://dx.doi.org/10.1146/annurev.pp.41.060190.002323

Li, S. Q., \& Zhang, Q. H. (2001). Advances in the development of functional foods from buckwheat. Critical Reviews in Food Science and Nutrition, 41, 451-464. http://dx.doi.org/10.1080/20014091091887

Lin, R. F., \& Chai, Y. (2007). Production, research and academic exchanges of China on buckwheat. In Y. Chai \& Z. W. Zhang (Eds.), Advance in Buckwheat Research: Proceedings of the 10th international symosium on buckwheat (pp. 7-12). Yangling, China: Northwest A \& F University Press.

Murakami, T., Yui, M., \& Amaha, K. (2012). Canopy height measurement by photogrammetric analysis of aerial images: Application to buckwheat (Fagopyrum esculentum Moench) lodging evaluation. Computers and Electronics Agriculture, 89, 70-75. http://dx.doi.org/10.1016/j.compag.2012.08.003 
Ookawa, T., \& Ishihara, K. (1993). Varietal difference of the cell wall components affecting the bending stress of the culm in relation to the lodging resistance in paddy rice (Oryza sativa). Japanese Journal of Crop Science, 62, 378-384. Retrieved from http://agris.fao.org/aos/records/JP9504071

Osakabe, Y., Ohtsubo, Y., Kawai, S., Katayama, Y., \& Morohoshi, N. (1995). Structure and tissue-specific expression of genes for phenylalanine ammonia-lyase from a hybrid aspen, Populus kitakamiensis. Plant Science, 105, 217-226. http://dx.doi.org/10.1016/0168-9452(94)04042-7

Prakash, S., \& Deshwal, S. (2013). Alpha and beta amylase activity of Fagopyrum esculentum (Buckwheat): A medicinal plant. Janaki Medical College Journal of Medical Science, 1, 53-58. http://dx.doi.org/10.3126/jmcjms.v1i1.7887

Rosler, J., Krekel, F., Amrhein, N., \& Schmid, J. (1997). Maize phenylalanine ammonia-lyase has tyrosine ammonia-lyase activity. Plant physiology, 113, 175-179. http://dx.doi.org/10.1104/pp.113.1.175

Sewalt, V. J. H., Ni, W. T., Blount, J. W., Jung, H. G., Masoud, S. A., Howles, P. A., ... Dixon, R. A. (1997). Reduced lignin content and altered lignin composition in transgenic tobacco down-regulated in expression of L-phenylalanine ammonia-lyase or cinnamate 4-hydroxylase. Plant physiology, 115, 41-50. http://dx.doi.org/10.1104/pp.115.1.41

Tripathi, S. C., Sayre, K. D., Kaul, J. N., \& Narang, R. S. (2004). Lodging behavior and yield potential of spring wheat (Triticum aestivum L.): effects of ethephon and genotypes. Field Crops Resarch, 87, 207-220. http://dx.doi.org/10.1016/j.fcr.2003.11.003

Turner, S. R., \& Somerville, C. R. (1997). Collapsed xylem phenotype of Arabidopsis identifies mutants deficient in cellulose deposition in the secondary cell wall. Plant Cell, 9, 689-701. http://dx.doi.org/10.1105/tpc.9.5.689

Wei, F. Z., Li, J. C., Wang, C. Y., Qu, H. J., \& Shen, X. S. (2008). Effects of nitrogenous fertilizer application model on culm lodging resistance in winter wheat. Acta Agronmica Sinica, 34, 1080-1085. http://dx.doi.org/10.3724/SP.J.1006.2008.01080

Wei, Y. M., Hu, X. Z., Zhang, G. Q., \& Ouyang, S. H. (2003). Studies on the amino acid and mineral content of buckwheat protein fractions. Food/Nahrung, 47, 114-116. http://dx.doi.org/10.1002/food.200390020

Welton, F. A. (1928). Lodging in oats and wheat. Botanical Gazette, 85, 121-151. Retrieved from http://www.jstor.org/stable/2470929

Zhang, J. N., Kang, L. X., Ji, Y. H., Feng, F. S., \& Sun, J. L. (1996). Effect of farmland windbreak on preventing rice lodging and yield reduction under violent tropical storm. Chinese Journal of Applied Ecology, 7, 15-18. Retrieved from http://www.cjae.net/CN/Y1996/V7/I1/15

\section{Copyrights}

Copyright for this article is retained by the author(s), with first publication rights granted to the journal.

This is an open-access article distributed under the terms and conditions of the Creative Commons Attribution license (http://creativecommons.org/licenses/by/3.0/). 